\title{
Cytoreductiv radikális prostatectomiával szerzett tapasztalataink oligometastaticus prosztatadaganatok esetében
}

\author{
Berczi Csaba dr. - Dócs János dr. - Flaskó Tibor dr. \\ Debreceni Egyetem, Általános Orvostudományi Kar, Urológiai Tanszék, Debrecen
}

\begin{abstract}
Bevezetés: Az utóbbi években az oligometastaticus prosztatadaganatok kezelése során a szisztémás kezelés mellett egyre gyakrabban végzik a primer tumor lokális kezelését is.

Célkitüués: A szerzók a tanulmányban a cytoreductiv radikális prostatectomia szerepét vizsgálták az oligometastaticus prosztatadaganatok kezelése során.

Módszer: 2012. 01. 01. és 2019. 01. 01. között összesen hét betegben végeztek cytoreductiv radikális prostatectomiát oligometastaticus prosztatadaganat esetében. A betegek átlagos életkora 64 év, az átlagos PSA-koncentráció $43 \mathrm{ng} / \mathrm{ml}$ volt. Az áttétek száma minden beteg vonatkozásában maximum három volt, és valamennyi esetben csontáttét volt jelen. A betegek androgéndeprivatiós hormonkezelést kaptak, és közülük négy esetben már a mútét előtt elkezdték a hormonterápiát. Négy betegnél a csontmetastasisok miatt az áttétek sugárkezelése is megtörtént.

Eredmények: A cytoreductiv prostatectomia szövettana öt esetben igazolt lokálisan előrehaladott (pT3) daganatot, és két alkalommal marginpozitivitás volt jelen. Emiatt öt beteg kapott adjuváns lokális irradiációt a metastasisok besugárzásán kívül. A mű́tétet követően biokémiai progresszió egy esetben jelentkezett. Ennek oka lokális recidíva volt, mely miatt a beteg 'salvage' irradiációt kapott. Az átlagosan 38 hónapos utánkövetés során új metastasist nem diagnosztizáltak, és tumor okozta halálozás nem fordult elő.

Következtetés: A cytoreductiv prostatectomia oligometastaticus prosztatarákos betegek kezelésében - válogatott beteganyagon - megvalósítható lehetőség. Ugyanakkor a cytoreductiv prostatectomia előnyei a tumorprogresszió szempontjából még nem egyértelmúek, ennek eldöntéséhez további vizsgálatok szükségesek.
\end{abstract}

Orv Hetil. 2021; 162(13): 483-487.

Kulcsszavak: prosztatadaganat, oligometastasis, cytoreductiv radikális prostatectomia

\section{Our experience with cytoreductive radical prostatectomy in patients with oligometastatic prostate cancer}

Introduction: In recent years, in addition to systemic therapy, local treatment of primary tumor has become increasingly common in the treatment of oligometastatic prostate cancers.

Objectve: The authors measured the role of cytoreductive radical prostatectomy in the treatment of oligometastatic prostate carcinoma.

Methods: From Janury 2012 to January 2019, they performed cytoreductive radical prostatectomy in seven patients with oligometastatic prostate cancer. The mean age of the patients was 64 years, and the mean PSA value was 43 $\mathrm{ng} / \mathrm{ml}$. The patients had maximum three distant metastases and all metastases were localized to the bones. The patients received androgene deprivation therapy and this treatment was started before the surgery in four cases. Irradiation of the bone metastasis was performed in four cases.

Results: The histology of the cytoreductive radical prostatectomy showed locally advanced tumor (pT3) in five patients and margin-positive status was present in two cases. Hence, adjuvant irradiation was administered locally in five patients in addition to the irradiation of bone metastases. Biochemical progression was detected in one patient during the follow-up period. It was caused by local recurrence of the tumor and the patient was treated with salvage irradiation. During the 38 months follow-up period neither new distant metastasis nor cancer-related mortality was detected. 
Conclusion: The cytoreductive radical prostatectomy is a feasible option in selected cases with oligometastatic prostate cancer. However, the benefits of cytoreductive radical prostatectomy regarding tumor progression are not clear yet and further studies are required.

Keywords: prostate cancer, oligometastasis, cytoreductive radical prostatectomy

Berczi Cs, Dócs J, Flaskó T. [Our experience with cytoreductive radical prostatectomy in patients with oligometastatic prostate cancer]. Orv Hetil. 2021; 162(13): 483-487.

(Beérkezett: 2020. július 20.; elfogadva: 2020. augusztus 16.)

\section{Rövidítések}

$\mathrm{ADT}=$ androgéndeprivatiós terápia; $\mathrm{CT}==($ computed tomography) számítógépes tomográfia; DE KK RKEB/IKEB = Debreceni Egyetem, Klinikai Központ, Regionális és Intézményi Kutatásetikai Bizottság; ECOG = (Eastern Cooperative Oncology Group) Keleti Kooperatív Onkológiai Csoport; MRI = (magnetic resonance imaging) mágnesesrezonanciaképalkotás; PET $/ \mathrm{CT}=$ (positron-emission tomography $/ \mathrm{com}$ puter tomography) pozitronemissziós tomográfiával kombinált számítógépes tomográfia; PSA = prosztataspecifikus antigén; PSMA = prosztataspecifikus membránantigén; RRP = retropubicus radikális prostatectomia; SEER = (surveillance epidemiology and end results) epidemiológiai megfigyelés és végeredmények; STAMPEDE $=($ Systemic Therapy for Advanced or Metastatic Prostate cancer: Evaluation of Drug Efficacy) szisztémás terápia előrehaladott vagy áttétes prosztatarák esetén: a gyógyszer hatékonyságának értékelése; TNM = tumor, nodus, metastasis; UICC $=($ Union for International Cancer Control $)$ Nemzetközi Rákellenőrzési Unió

A metastaticus prosztatacarcinomás betegek kezelésére évtizedek óta az androgéndeprivatiós hormonkezelést (ADT) végzik standard terápiaként. Napjainkban azonban a metastaticus prosztatadaganatok kezelése során a hagyományos hormonkezelés mellett elterjedtebben alkalmaznak korai kemoterápiát vagy új típusú hormonkészítményeket. Ezen kombinált kezelésekkel a metastaticus prosztatadaganatok terápiájának eredményessége jelentősen nőtt, de az ötéves túlélés még így is 30\% körül van, és gyakoriak a primer tumor okozta helyi szövődmények [1, 2]. Több vizsgálat kimutatta, hogy az ADT ellenére a prosztatában a tumorklónok perzisztálnak [3]. Tekintettel arra, hogy a metastaticus tumorok jelenlegi terápiájának eredményessége az elvártnál alacsonyabb, más kezelési lehetőségek is felmerültek. Egyes tanulmányok azt mutatták, hogy több metastaticus tumornál - így a prosztatadaganatnál is - a szisztémás kezelés mellett a primer tumor lokális kezelése túlélési előnnyel járhat. Ennek hátterében az az elméleti megfontolás áll, hogy amennyiben a primer, lokális tumor kezeletlenül marad, úgy az szerepet játszhat a meglevő metastasisok progressziójában és új áttétek kialakulásában $[4,5]$. Az oligometastaticus tumoroknál végzendő cytoreductiv mütétek hatékonyságával kapcsolatos teóriát 1995-ben Hellman közölte [6]. Az utóbbi években az oligometas- taticus prosztatadaganatok terápiájával kapcsolatban több közleményben arról számoltak be, hogy a hagyományos hormonkezelés mellett a primer daganatra alkalmazott lokális kezelés túlélési előnyt nyújthat [7-9].

Jelen tanulmányunkban az oligometastaticus prosztatadaganatos betegek esetében végzett cytoreductiv radikális prostatectomiával szerzett tapasztalatainkat mutatjuk be, és áttekintjük az ezzel kapcsolatos irodalmi adatokat.

\section{Betegek és módszerek}

2012. 01. 01. és 2019. 01. 01. között klinikánkon öszszesen hét beteg esetében végeztünk cytoreductiv radikális prostatectomiát újonnan diagnosztizált oligometastaticus prosztatadaganat miatt.

A betegek átlagéletkora 64 év volt, koruk 60 és 69 év között változott. Az átlagos PSA-szint $43 \mathrm{ng} / \mathrm{ml}$ volt (9,9 és $120 \mathrm{ng} / \mathrm{ml}$ között változott). A prosztatabiopsziák Gleason-score-értéke, valamint a betegek adatai az 1. táblázatban vannak feltüntetve. A Gleason-értékek megadása a 2014. évi Gleason-rendszer alapján történt.

Valamennyi esetben kismedencei MR-, hasi CT- és csontizotóp-vizsgálat történt a tumor lokális kiterjedésének és a távoli áttétek vizsgálatának céljából. Az MRvizsgálatok két betegnél mutattak lokálisan előrehaladott daganatot, mely tumorosan beszürte az ondóhólyagokat, de nyirokcsomóáttét egyik betegnél sem volt észlelhető. A csontizotóp-vizsgálat valamennyi betegnél maximum három csontáttétet diagnosztizált. A képalkotó vizsgálatok a csontokon kívül máshol nem mutattak metastasist.

A betegekkel a daganat kezelési lehetőségeit megbeszéltük, és a beleegyezésük, illetve több esetben a kérésük alapján végeztük el a cytoreductiv radikális prostatectomiát. A betegfelvilágosítás során tájékoztattuk őket, hogy a metastaticus prosztatadaganatok standard kezelése az androgéndeprivatiós hormonkezelés. Ismertettük azt is, hogy egyes vizsgálatok eredményei azt mutatták, hogy a hormonkezelés mellett alkalmazott lokális kezelés (sugárkezelés vagy mütét) túlélési előnyt nyújtott. A betegbevonási kritériumok a következők voltak: technikailag teljesen eltávolítható prosztatatumor, a csontáttétek száma maximum három, nincsenek nagy (kisme- 
1. táblázat | Klinikopatológiai adatok és mútét utáni szekunder kezelések

\begin{tabular}{|c|c|c|c|c|c|c|c|c|}
\hline & 1. beteg & 2. beteg & 3. beteg & 4. beteg & 5. beteg & 6. beteg & 7. beteg & Átlag \\
\hline Kor (év) & 69 & 67 & 60 & 68 & 62 & 61 & 60 & 64 \\
\hline Charlson-féle komorbiditási index & 1 & 1 & 0 & 2 & 1 & 0 & 1 & \\
\hline ECOG-status & 1 & 1 & 0 & 0 & 0 & 0 & 0 & \\
\hline PSA $(\mathrm{ng} / \mathrm{ml})$ & 9,9 & 41,8 & 9,7 & 120 & 32 & 36 & 52 & 43 \\
\hline Biopszia, Gleason-score & $4+4=8$ & $1+1=2 *$ & $4+5=9$ & $3+3=6$ & $3+2=5$ & $4+5=9$ & $4+3=7$ & \\
\hline $\mathrm{cT}$ & $\mathrm{T} 2$ & $\mathrm{~T} 2$ & T3 & $\mathrm{T} 2$ & T3 & $\mathrm{T} 2$ & $\mathrm{~T} 2$ & \\
\hline $\mathrm{cN}$ & N0 & N0 & N0 & N0 & N0 & N0 & N0 & \\
\hline A csontáttétek száma & 1 & 1 & 2 & 3 & 2 & 3 & 3 & \\
\hline Mütét elött hormon & 0 & 0 & 0 & 1 & 1 & 1 & 1 & \\
\hline Mütéti típus & LAP RP & LAP RP & LAP RP & LAP RP & LAP RP & RRP & RRP & \\
\hline Clavien-Dindo-féle grade & 0 & 0 & 1 & 0 & 0 & 0 & 0 & \\
\hline $\mathrm{pT}$ & T3 & $\mathrm{T} 2$ & T3 & $\mathrm{T} 2$ & T3 & T3 & T3 & \\
\hline $\mathrm{pN}$ & N0 & N0 & N0 & N0 & N0 & N0 & N0 & \\
\hline Gleason-score & $4+5=9$ & $4+3=7$ & $4+5=9$ & $\mathrm{X}$ & $4+3=7$ & $4+5=9$ & $4+5=9$ & \\
\hline Marginpozitivitás & 0 & 0 & 0 & 0 & 1 & 0 & 1 & \\
\hline PSA-emelkedés & 1 & 0 & 0 & 0 & 0 & 0 & 0 & \\
\hline Lokális recidíva & 1 & 0 & 0 & 0 & 0 & 0 & 0 & \\
\hline Távoli metastasis & 0 & 0 & 0 & 0 & 0 & 0 & 0 & \\
\hline Követés (év) & 7,5 & 1,2 & 4,3 & 4,2 & 0,7 & 2,2 & 2,4 & 3,2 \\
\hline Exit & 0 & 0 & 0 & 0 & 0 & 1 & 0 & \\
\hline Mütét után hormon & 0 & 0 & 1 & 1 & 1 & 1 & 1 & \\
\hline 'Salvage' hormon & 1 & 0 & 0 & 0 & 0 & 0 & 0 & \\
\hline Adjuváns irradiáció & 0 & 0 & 1 & 1 & 1 & 1 & 1 & \\
\hline 'Salvage' irradiáció & 1 & 0 & 0 & 0 & 0 & 0 & 0 & \\
\hline
\end{tabular}

Charlson-féle komorbiditási index: nem korillesztett Charlson-féle komorbiditási index

X: a 4. beteg esetében az előzetes hormonkezelés miatt a szövettani vizsgálatnál nem tudták megadni az eltávolított prosztatában levő tumor Gleason-score-értékét

*a 2. betegnél a biopszia más intézetben történt

ECOG $=$ Keleti Kooperatív Onkológiai Csoport; LAP RP = laparoszkópos radikális prostatectomia, PSA = prosztataspecifikus antigén; RRP = retropubicus radikális prostatectomia

dencei vagy retroperitonealis) nyirokcsomók, nincs visceralis áttét, a beteg ECOG-statusa nem nagyobb, mint egy, és a beteg írásban beleegyezett.

A mútét öt betegben laparoszkópos és két betegben nyílt mútéti feltárással történt. A mútétek során azon esetekben, amikor a beteg általános állapota miatt laparoszkópos beavatkozás nem volt elvégezhető, nyílt mütét történt. A mütét során valamennyi esetben kiterjesztett nyirokcsomó-eltávolítást is végeztünk.

A daganat stádiumának meghatározása az UICC 2016. évi TNM-rendszere szerint történt.

Egy vagy két csontmetastasis esetén az áttétek sugárkezelését is elvégeztük a mütétet követően. A betegek a metastaticus daganat miatt androgéndeprivatiós hormonkezelésben részesültek. Négy beteg esetében a hormonkezelés már a mütét előtt elindult. A betegek biszfoszfonátkezelést nem kaptak.

A betegek utánkövetése során PSA-vizsgálat az első három évben háromhavonta, azt követően, amennyiben progresszió nem jelentkezett, hathavonta történt. Csont- izotóp-vizsgálatot évente végeztünk. Egyéb képalkotó vizsgálat $(\mathrm{CT}, \mathrm{MRI})$ végzésére PSA-emelkedés vagy a beteg panaszai miatt került sor.

\section{Eredmények}

A mútét előtt négy beteg kapott androgéndeprivatiós hormonkezelést, s közülük három esetben a PSA 1 ng/ ml alá, míg egy betegben a PSA 120 ng/ml-ről 8 ng/ ml-re csökkent.

A mütétet követően összesen egy betegnél jelentkezett Clavien-Dindo szerinti grade 1-es szövődmény. Ez a cisztogramon észlelt, egyébként tünetmentes vizeletszivárgás volt az anastomosisnál, mely miatt a hólyagkatétert egy héttel később távolítottuk el.

A cytoreductiv radikális prostatectomia szövettana öt esetben igazolt lokálisan előrehaladott (pT3) daganatot, és két alkalommal a sebészi szél tumoros infiltrációját mutatta. A lokálisan előrehaladott tumor miatt az emlí- 
tett öt beteg adjuváns lokális irradiációban részesült. A mütétet követően a metastasisok besugárzását négy betegnél végeztük el. Ezen betegeknek egy, illetve két csontáttétük volt.

A távoli áttétek miatt alkalmazandó hormonkezelést egy beteg visszautasította, így összesen csak hat beteg kapott ADT-t a mútét után.

A mútétet követően biokémiai progresszió egy esetben jelentkezett. Ennek oka lokális recidíva volt, mely miatt a beteg 'salvage' irradiációt kapott. Ez volt az a beteg, aki a mütét után nem egyezett bele a hormonkezelésbe. A PSA-emelkedés miatt most viszont beleegyezett, és így ADT-t is indítottunk.

Az átlagosan 38 hónapos utánkövetés során új metastasist nem diagnosztizáltunk, és tumor okozta halálozás nem fordult elő.

\section{Megbeszélés}

A metastaticus prosztatadaganatok esetében a lokális kezelés észszerűségét több preklinikai tanulmány igazolta. Az újonnan kialakult távoli áttétek száma szignifikánsan csökkent az állatmodelleken végzett kísérletek során, ha prostatectomiát is végeztek, ellentétben azokkal, akik csak ADT-ben részesültek [3]. A primer tumor eltávolítása megszüntetheti azon citokinek forrását, melyek a metastaticus tumorsejtek terjedését serkentik, és csökkentheti a legagresszívebb tumorsejtek proliferációját [10-12]. Természetesen a tumor volumenének csökkentése szintén javíthatja a szisztémás kezelésre adott választ.

$\mathrm{Az}$ oligometastaticus prosztatadaganatokkal kapcsolatban több tanulmány azt mutatta, hogy ezen betegek prognózisa kedvezőbb, és jobb a túlélésük, valamint hogy maga az oligometastaticus állapot prediktor a túlélés szempontjából $[13,14]$. Az, hogy mit értünk oligometastaticus prosztatadaganaton, nem teljesen tisztázott. Vannak szerzők, akik úgy definiálják az oligometastasis fogalmát, hogy az áttétek száma nem lehet több ötnél, mások úgy értelmezik, hogy nem több háromnál. 2015-ben a St. Gallen-i 'Advanced Prostate Cancer Consensus Conference' úgy határozta meg, hogy az tekinthető oligometastaticus prosztatadaganatnak, amikor az áttétek száma nem több háromnál [15]. Az oligometastasisok diagnosztikájával kapcsolatban sokan megjegyzik, hogy a CT- és a csontizotóp-vizsgálat érzékenysége nem megfelelő, így nem biztos, hogy valóban csak annyi áttét van. Az áttétek számának pontos kimutatására jelenleg a legjobb érzékenysége a PET/CT vizsgálatoknak (kolin- és PSMA-PET/CT) van [16, 17].

A metastaticus prosztatadaganatok primer lokális kezelése történhet mütéttel vagy sugárkezeléssel. Az ilyen esetekben végzett sugárterápiával kapcsolatban eddig két, randomizált klinikai tanulmányt végeztek: a HORRAD- és a STAMPEDE-vizsgálatot. Ezek mindegyike szerint javult a túlélés, amikor a primer daganat irradiációja is megtörtént $[18,19]$. A STAMPEDE-vizsgálat eredményei azt mutatták, hogy a kis volumenú me- tastaticus prosztatadaganatok esetében túlélési előnnyel járt a primer tumor sugárkezelése azon betegekhez viszonyítva, akik csak szisztémás kezelésben részesültek [19]. Azt is tapasztalták, hogy a betegek harmadában szükséges volt palliatív lokális terápia a helyileg progrediáló tumor miatt $[19,20]$.

Az oligometastaticus prosztatadaganatok kezelésével kapcsolatban jelenleg nincs olyan randomizált klinikai tanulmány, mely a cytoreductiv radikális prostatectomiával együtt alkalmazott ADT-t hasonlította volna össze a csak ADT-t kapott betegcsoporttal. Ha azonban logikusan végiggondoljuk a dolgot, látható, hogy ha az oligometastaticus prosztatadaganatok esetében a primer tumor sugárkezelése túlélési előnnyel jár, akkor ugyanez igaz lehet a primer tumor mútéttel történő eltávolítására is.

Sooriakumaran és mtsai a cytoreductiv radikális prostatectomiával kapcsolatos, több intézet bevonásával végzett, nagy esetszámú retrospektív tanulmányukban a medián 22 hónapos utánkövetés során 88,7\%-os túlélésről számoltak be [21].

Heidenreich és mtsai oligometastaticus prosztatadaganatos betegeken végzett eset-kontroll tanulmányukban vizsgálták a progressziómentes és a tumorspecifikus túlélést. A radikális prostatectomiát és ADT-t kapott csoportban a tumorspecifikus és a progressziómentes túlélés 47 és 38,6 hónap volt, szemben a csak ADT-t kapott betegcsoporttal, amelynél a tumorspecifikus és a progressziómentes túlélés 40 és 26,5 hónap volt [22].

A SEER adatbázisának felhasználásával végzett tanulmány során a metastaticus prosztatadaganatos betegek kezelésével kapcsolatban megállapították, hogy az ötéves tumorspecifikus túlélés szignifikánsan jobb volt, ha a primer tumor mútéti vagy sugárkezelése is megtörtént $(75,8 \%$ vs. $48,7 \%)$ [23].

Gratzke és mtsai a Müncheni Rákregiszternek a metastaticus prosztatadaganatos betegekkel kapcsolatos adatait elemezve azt tapasztalták, hogy azon betegek ötéves túlélése szignifikánsan jobb volt, akik a szisztémás kezelés mellett radikális prostatectomián is átestek (55\% vs. 21\%) [24].

Egy nagy, szelektált beteganyagon, több intézmény bevonásával végzett retrospektív vizsgálatban azt tapasztalták, hogy azon betegek esetében, akiknél cytoreductiv prostatectomiát is végeztek, a hároméves és az ötéves tumorspecifikus túlélés 89,3\% és 80,5\% volt [25].

Több, a témával kapcsolatos vizsgálat és összefoglaló közlemény azt a következtetést vonta le, hogy a cytoreductiv radikális prostatectomia javítja a progressziómentes túlélést, és megnyújtja a kasztrációrezisztens prosztatadaganat kialakulásáig eltelt időt. A cytoreductiv radikális prostatectomia hatékony a tumor terjedésének megelőzésére és az ezzel kapcsolatos szövődmények elkerülésére [1, 7, 8, 20, 22-24, 26].

Saját eseteinkben a betegek utánkövetése során biokémiai progressziót egy esetben észleltünk, és a csaknem hároméves utánkövetés alatt tumor okozta halálozás nem fordult elő. 


\section{Következtetés}

Elmondhatjuk, hogy a cytoreductiv prostatectomia az oligometastaticus prosztatarákos betegek válogatott csoportjában a követendő terápia. Ugyanakkor a cytoreductiv prostatectomia előnyei a tumorprogresszió szempontjából még nem egyértelmúek, ezért a cytoreductiv prostatectomia eredményességének megítélésére további vizsgálatok szükségesek.

Anyagi támogatás: A közlemény megírása, illetve az azzal kapcsolatos kutatómunka anyagi támogatásban nem részesült.

Szerzôi munkamegosztás: B. Cs.: A vizsgálat megtervezése, a cikk megírása. D. J.: Adatgyüjtés. F. T.: Szakmai felügyelet. A cikk végleges változatát valamennyi szerző elolvasta és jóváhagyta.

Érdekeltségek: A szerzőknek nincsenek érdekeltségeik.

A DE KK RKEB/IKEB engedély száma: 5503-2020.

\section{Irodalom}

[1] Mathieu R, Korn SM, Bensalah K, et al. Cytoreductive radical prostatectomy in metastatic prostate cancer: does it really make sense? World J Urol. 2017; 35: 567-577.

[2] Wu JN, Fish KM, Evans CP, et al. No improvement noted in overall or cause-specific survival for men presenting with metastatic prostate cancer over a 20-year period. Cancer 2014; 120 : 818-823.

[3] Cifuentes FF, Valenzuela RH, Contreras HR, et al. Surgical cytoreduction of the primary tumor reduces metastatic progression in a mouse model of prostate cancer. Oncol Rep. 2015; 34: 2837-2844.

[4] Antwi S, Everson TM. Prognostic impact of definitive local therapy of the primary tumor in men with metastatic prostate cancer at diagnosis: a population-based, propensity score analysis. Cancer Epidemiol. 2014; 38: 435-441.

[5] Morrow M, Goldstein L. Surgery of the primary tumor in metastatic breast cancer: closing the barn door after the horse has bolted? J Clin Oncol. 2006; 24: 2694-2696.

[6] Hellman S, Weischelbaum RR. Oligometastases. J Clin Oncol. 1995: 13: 8-10

[7] Gandaglia G, Fossati N, Stabile A, et al. Radical prostatectomy in men with oligometastatic prostate cancer: results of a singleinstitution series with long-term follow-up. Eur Urol. 2017; 72: 289-292

[8] Heidenreich A, Pfister D. Radical cytoreductive prostatectomy in men with prostate cancer and oligometastatic disease. Curr Opin Urol. 2020; 30: 90-97.

[9] Mandel P, Steuber T, Graefen M. Radical prostatectomy in oligometastatic prostate cancer. Curr Opin Urol. 2017; 27: 572579.

[10] Bayne CE, Williams SB, Cooperberg MR, et al. Treatment of the primary tumor in metastatic prostate cancer: current concepts and future perspectives. Eur Urol. 2016; 69: 775-787.
[11] Szarvas T, Csizmarik A, Szúcs M, et al. Molecular subtypes and perspectives of targeted therapies in prostate cancer. [A prosztatarák molekuláris altípusai és célzott terápiás kilátásai.] Orv Hetil. 2019; 160: 252-263. [Hungarian]

[12] Kim MY, Oskarsson T, Acharyya S, et al. Tumor self-seeding by circulating cancer cells. Cell 2009; 139: 1315-1326.

[13] Gandaglia G, Karakiewicz PI, Briganti A, et al. Impact of the site of metastases on survival in patients with metastatic prostate cancer. Eur Urol. 2015; 68: 325-334.

[14] Halabi S, Kelly WK, Ma H, et al. Meta-analysis evaluating the impact of site of metastasis on overall survival in men with castration-resistant prostate cancer. J Clin Oncol. 2016; 34: 16521659 .

[15] Gillessen S, Omlin A, Attard G, et al. Management of patients with advanced prostate cancer: recommendations of the St Gallen Advanced Prostate Cancer Consensus Conference (APCCC) 2015. Ann Oncol. 2015; 26: 1589-1604. [Erratum: Ann Oncol. 2019; 30: e3.]

[16] Farkas I, Besenyi Zs, Maráz A, et al. Initial experiences with ${ }^{99 \mathrm{~m} T c-P S M A-S P E C T / C T}$ in patients with prostate cancer. [Kezdeti tapasztalatok a ${ }^{99 \mathrm{~m} T \mathrm{~T}-P S M A-S P E C T / C T-v e l ~ p r o s z t a t a r a ́ k o s ~}$ betegekben.] Orv Hetil. 2018; 159: 1433-1440. [Hungarian]

[17] Tosoian JJ, Gorin MA, Ross AE, et al. Oligometastatic prostate cancer: definitions, clinical outcomes, and treatment considerations. Nat Rev Urol. 2017; 14: 15-25.

[18] Boevé LM, Hulshof MC, Vis AN, et al. Effect on survival of androgen deprivation therapy alone compared to androgen deprivation therapy combined with concurrent radiation therapy to the prostate in patients with primary bone metastatic prostate cancer in a prospective randomised clinical trial: data from the HORRAD trial. Eur Urol. 2019; 75: 410-418.

[19] Parker CC, James ND, Brawley CD, et al. Radiotherapy to the primary tumour for newly diagnosed, metastatic prostate cancer (STAMPEDE): a randomised controlled phase 3 trial. Lancet 2018; 392: 2353-2366.

[20] Tilki D, Pompe RS, Bandini M, et al. Local treatment for metastatic prostate cancer: a systematic review. Int J Urol. 2018; 25: $390-403$.

[21] Sooriakumaran P, Karnes J, Stief C, et al. A multi-institutional analysis of perioperative outcomes in 106 men who underwent radical prostatectomy for distant metastatic prostate cancer at presentation. Eur Urol. 2016; 69: 788-794.

[22] Heidenreich A, Pfister D, Porres D. Cytoreductive radical prostatectomy in patients with prostate cancer and low volume skeletal metastases: results of a feasibility and case-control study. J Urol. 2015; 193: 832-838.

[23] Culp SH, Schellhammer PF, Williams MB. Might men diagnosed with metastatic prostate cancer benefit from definitive treatment of the primary tumor? A SEER-based study. Eur Urol. 2014; 65: 1058-1066.

[24] Gratzke C, Engel J, Stief CG. Role of radical prostatectomy in metastatic prostate cancer: data from the Munich Cancer Registry. Eur Urol. 2014; 66: 602-603.

[25] Heidenreich A, Fossati N, Pfister D, et al. Cytoreductive radical prostatectomy in men with prostate cancer and skeletal metastases. Eur Urol Oncol. 2018; 1: 46-53.

[26] Nair R, Lamb BW, Geurts N, et al. The role of local therapy for oligometastatic prostate cancer: should we expect a cure? Urol Clin North Am. 2017; 44: 623-633.

(Berczi Csaba dr., Debrecen, Nagyerdei krt. 98., 4032 e-mail: berczi@med.unideb.hu)

A cikk a Creative Commons Attribution 4.0 International License (https://creativecommons.org/licenses/by/4.0/) feltételei szerint publikált Open Access közlemény, melynek szellemében a cikk bármilyen médiumban szabadon felhasználható, megosztható és újraközölhetö, feltéve, hogy az eredeti szerzỏ és a közlés helye, illetve a CC License linkje és az esetlegesen végrehajtott módosítások feltüntetésre kerülnek. (SID_1) 